\title{
CD276 wt Allele
}

National Cancer Institute

\section{Source}

National Cancer Institute. CD276 wt Allele. NCI Thesaurus. Code C93064.

The CD276 wild-type allele is located within 15q23-q24 and is approximately $30 \mathrm{~kb}$ in length. This allele, which encodes CD276 antigen protein, plays a role in regulation of both the immune response and $\mathrm{T}$ cell proliferation. 